\title{
Determinants of real decision making on productive components of consumption under the current economic conditions of the Slovak Republic
}

\author{
Marianna Psárska ${ }^{1, *}$ \\ ${ }^{1}$ Institute of Technology and Business in České Budějovice, School of Expertness and Valuation, \\ Okružní 517/10, 37001 České Budějovice, Czech Republic
}

\begin{abstract}
The aim of the contribution is to determine the main determinants of the formation of their productive components in consumption under the real conditions of the selected country, using the decision-making mechanism of the individual and of the households. The benefit of the article is in particular applied bonding and verification of the relation between the current theories and the practice that is realized through a questionnaire survey. By recognizing these determinants the partial decision-making issues will be clarified and it will open the space for the eventual desired behavior of household behavior in specific Slovak Republic conditions. The conclusions of the article point out that household decision-making is influenced by several factors in parallel, but psychological factors play a very important role. It is clear from the conclusions that Slovak households, by their decision, confirm theories of behavioral economists even when deciding on productive components in consumption.
\end{abstract}

Key words: productive components of consumption, rational decisionmaking, irrational decision-making, quality of life, determinants of consumption

\section{Introduction}

If we want to monitor the selected components or certain categories of the consumer basket of households, it is necessary for us to first understand their decision making mechanism from a theoretical and practical point of view. This is the key to understanding the shaping of consumption that is inevitably built on the individual he is looking for in the consumer sense. We understand households as recipients and consumers of pensions, but also as creators of savings. In this category, basic descriptive characteristics such as who is at the forefront of household preference, the number of dependent children where the household lives, its size, structure, age, and so on are important. This explains in part the motives of individual population groups, their basic tendencies in decision making and the tendencies of the future development of the studied components of consumption.

\footnotetext{
* Corresponding author: psarska.m@gmail.com
} 
The choice of the category of household and individual is linked to the methodological individualism of the neoclassical school. It is an approach that explains all economic categories and laws to the rational behavior of an isolated individual, "Economic human" (homo oeconomicus) [1].

In principle, at present, households use products, but individuals usually buy them. There are different models of household decision-making (family), but they are dealt with in detail in marketing. We are going back to the decision-making mechanism and the powers that make the most of it. The decision process can be explained by a general logical description of the consumer's decision-making situation. The basic decision model is actually a system model, and it consists in practice of ten basic elements [2].

\subsection{Rational decision-making}

One of the axes of economic theory is the claim that a person decides rationally. Rationality is understood as a reason-based action. However, setting criteria for rational decisionmaking is rather complex because individuals perceive rationality differently. The basic concept of rationality is the "homo oeconomicus" paradigm, which has remained the focus of economists' attention to rationality, even though it has been the subject of constant criticism [3].

The pillars of rational decision-making consist in the fact that:

- a person acts in such a way to achieve a better situation than the one he is in;

- the paths that lead people to their goal are important. And here a person chooses the most effective ways to reach their goal with minimal distress and maximum benefit;

- the basic principle of optimal behavior is that a person continues to operate while their costs are below his marginal yield (or borderline utility);

- a person can only explain the behavior of people in a large group;

- In a large group there are interchange relationships based on people, that is, the market and the core coordinator is the price;

- a person makes mistakes but learns and does not repeat them;

- A rational person does not get all the information, he does not want to be fully informed. Rational behavior is characterized by rational ignorance, which is, in fact, an optimal level of awareness when, the borderline yield from information equals the borderline cost of information;

- the principle of optimization is based on the claim that a person uses their limited resources in an optimal way when deciding. Microeconomic analysis is based on the ability of a person to choose or prioritize one solution from a set of permissible solutions at the limit of their consumer options [4];

- The "homo oeconomicus" paradigm is based on the fact that the purpose and goal of human behavior is to best satisfy its individual needs while ignoring the consumption of other people. It is therefore based on egoistic preferences and the ability to always find the best optimal solution to maximize their own usefulness. This subtle rationality is also referred to as complete or equivalent or unlimited [5];

Pillars of rational decision-making also include two basic standards that serve to analyze rational human behavior. Formal theory of rational behavior consists of the rationality standard of self-interest and rationality, of the current target [6].

\subsection{Alternative approaches to rationality}

Alternative approaches to rationality can be considered a modern development of the neoclassical homo oeconomicus paradigm. They point to the weaknesses of this paradigm, the current economic and non-economic issues related to consumer decision-making. 
Alternative approaches ponder rationality as limited (imperfect). The limited rationality is connected and explained through the principle of satisfaction, cognitive imperfection and the concept of altruism.

The principle of satisfaction lies in the fact that one does not seek an optimal variant indefinitely, but the evaluation process ends when he finds a satisfactory solution. He does not look for an optimal solution, but an acceptable one. Another one is the principle of imperfection that describes the consequences of human imperfections such as hesitancy, evasiveness, and so on. The concept of altruism captures the situation when one also includes the benefits for other people in their decision-making motives [7].

A limited rationality is manifested by the fact that a person is not always able to apply the expenditure and income calculations immediately, and decides to be uncertain. his decision may be influenced by the cost of obtaining information, or it is realized under the influence of emotions. Psychology, which is influenced by behavioral economics, also has a major impact. It realizes an optimally satisfactory solution to its situation.

Behavioral Economics $\uparrow$ combines psychology with economics to provide answers to many challenging questions about economic decision-making in the current times. It deals with the circumstances of individuals' failures and the causes of crises. Behavioral economics justifies the emergence of crises by the fact that all behave equally irrationally. As a result, there are bubbles in the markets. In a summarized form, research into behavioral economists has shown that:

- emotions greatly affect a person's behavior, and a person is acting differently as an individual and differently in a crowd;

- a person prefers choosing an alternative that brings change of wealth, but when choosing from alternatives, the most important role is not played by static wealth, but its relative expression and relative change over a reference point, plays the most important role.

- Human behavior is motivated by two major systems. One is based on looking for rewards and the other on resistance to loss;

- intuitive judgment belongs to the same place as deliberate thought activities;

people misrepresent themselves as they act reasonably and deliberately, but they are actually influenced and vulnerable and repeatedly making misconceptions in bad shopping and investment decisions. These decisions are therefore not only irrational but even predictably irrational;

- we avoid comparing things that need to be very thought out;

- the so-called effect of herd behavior that occurs when we form an opinion based on the opinion of other people;

- the endogenous preferences for which habits, customs, reference group pressure, parental influence on children's preferences, advertising, love and affection have an effect on the maximalization of utility. Thus, the model of dependence of current and future preferences on past personal experiences or social influences on preference making and many others is working.

In our article, given the complexity of the issue, we will only focus on a selected category of productive components of individual consumption, specifically households.

\footnotetext{
${ }^{\dagger}$ Behavioral Economics applies the results of research on human cognitive and emotional tendencies in explaining economic decisions and explaining how these tendencies affect market prices, revenue and resource allocation. Behavioral models integrate the knowledge of psychology into neoclassical economics.
} 


\subsection{Productive components in consumption and their key determinants}

If we want to examine the selected product aspects of household consumption theoretically, we must use the alternative approach to rationality. Economics of Productive Consumption according to R. Valencik [8] considers the household behavior and the growth of the present value of the expected future income from the creation and operation of assets forming their "family portfolio". Under the productive components of consumption we mean those items of the consumer basket of households, which by their nature are investments in human and social capital. These are therefore components of consumption that are not necessary for survival, and their importance in the consumer basket is increasing only after reaching a certain standard of living for households. The fact is that in developed countries the importance of productive components of household consumption is growing especially when economies are at the peak of the economic cycle when these spending groups should reach the highest values. The question, however, is why it is not, for example, in Slovakia. In the context of decision-making about their consumption, it is necessary to know the process of implementing these decisions [2].

In general, we distinguish the four main content groups of determinants affecting consumption and consumer behavior. They are economic, social, demographic and other determinants. We consider economic factors as the primary premise for their application as the most important and as the determinants of the productive components.

But let us go back to the process of making decisions about these components of consumption. From the point of view of behavioral economy preferences [9-13], one prefers to choose an alternative that brings a change of wealth. Productive components of consumption definitely bring this possibility of change of wealth. The question, however, is whether the real households are really aware of this fact. Or is it just applicable to a tiny percentage of households?

Because the behavioral approach is based on the assumption that human behavior is motivated by two main systems, namely seeking rewards or avoiding losses. Is it therefore necessary to consider what rewards do productive components of consumption bring and whether there is any kind of loss? And also the question of how can the productive components of household consumption be protected from risks? Questions of this type lead us to the motives that lead people to spend their money on any kind of expenditure.

According to D. Kahneman [14], the current view of consumer decision-making is focused on three main themes, namely heuristics of judgment, risky choices and framing. In all three areas thoughts, intuitions and preferences were studied, which a person thinks about quickly and without long pondering. D. Kahneman and A. Tversky argue that intuitive judgment belongs to the same place as deliberate thinking, but focuses on the existing discrepancies between intuition and knowledge especially in statistics. Are the productive components of household consumption relevant to intuitive or deliberate thought processes, or does the human nature play a major role in these issues? D. Kahnemann also deals with the formalization of intuition and the issue of change of wealth or function of values.

Another author of behavioral economics is D. Ariely [15], who has attributed an important role in the decision making process to the so-called accidental dependence and anchors from the past. Are productive components of consumption also decided in this way? The analysis of D. Ariely, which focuses on the magic word "FREE", is a very exciting one, as we often make a decision which we did not want in the first place and which is not the best from the point of view of rational decision-making. Whatever is free, it seems to us a lot more valuable than what it really is. And why? Because human beings have instinctive fear of loss [3]. The success of this word is based on this fact and is often used, for example, in pharmacies for the sale of supplementary medications, and thus falls under household spending on healthcare and productive components of consumption. 
Another point of view on this issue is the G. S. Becker theory, which, for example, considers habit (rationality) to be rational if the increase in past consumption increases current consumption [16]. For reflection on the rationality of custom behavior, the key point is the knowledge that the extent of addictive activities is relatively high in humans, so we can not exclude them from economic analyzes. Is it possible that just the habit of free public education within our economic system and family is just the necessary minimum spending that hampers the possible change from the point of view of their development and the growth of well-being in the long run? Or is there another cause?

If we knew the answers to these questions, it would be possible not only to better understand people, but also help them in the sense of better choice of purchased goods and services supporting productive components of household consumption, which in the long run would bring about the growth of their wealth and their role in the company has the ability to create much more added value.

We will end this part of the article with R. Thaler's work, analyzing how people can be encouraged to make better decisions. It outlines how governments can use behavioral models to increase the efficiency and quality of a wide range of public services. By which it points out some sort of possible positive interaction or correct motivation to change behavior even in our conditions. R. Thaler's research can also be applied to everyday human economic decisions as well as to the behavior of the whole market. In his work, he incorporated psychologically realistic thinking into economic decision-making. His research into the impacts of limited human rationality, social priorities and lack of selfcontrol shows how these human characteristics systematically influence economic decisionmaking of individuals [17, 23, 24, 25].

\section{Data and methods}

The examined data for the purpose of this contribution were surveyed through an anonymous questionnaire survey on the productive componens of consumption and the implementation of the decision-making mechanism of specific individuals.

Overall, the questionnaire survey consists of two parts and has 25 questions. The first part is focused on the descriptive characteristics (see Table 1) in terms of determining the status of household preference, the number of dependent children in households, the level of net income, or the basic characteristics of the person surveyed. The second part deals with the issue of consumption, where the questionnaire survey contained categories of spent expenditure on healthcare, education, recreation and culture, and also included open questions, which gave us the opportunity to highlight the motives of decision-making and gained many insights into the selection of other perspective components of the expenditures of productive character. 
Table 1. Descriptive characteristics of the target sample (Survey questions 1-3)

\begin{tabular}{|l|c|l|c|l|c|}
\hline Question (1.) & $\begin{array}{c}\text { Position in } \\
\text { household }\end{array}$ & Question (2.) & $\begin{array}{c}\text { No. of } \\
\text { children in } \\
\text { the } \\
\text { household }\end{array}$ & Question (3.) & $\begin{array}{c}\text { Net } \\
\text { income }\end{array}$ \\
\hline Retiree & $2.53 \%$ & $\begin{array}{l}\text { Without } \\
\text { children }\end{array}$ & $50.63 \%$ & below 500 Eur & $50.63 \%$ \\
\hline Maternal leave & $2.53 \%$ & With 1 child & $22.78 \%$ & $\begin{array}{l}\text { from } 500 \text { to } 1000 \\
\text { Eur }\end{array}$ & $3.80 \%$ \\
\hline $\begin{array}{l}\text { Self-employed } \\
\text { person }\end{array}$ & $11.39 \%$ & With 2 children & $22.78 \%$ & $\begin{array}{l}\text { from } 1000 \text { to } \\
1500 \text { Eur }\end{array}$ & $22.78 \%$ \\
\hline Employee & $83.54 \%$ & $\begin{array}{l}\text { With 3 and } \\
\text { more children }\end{array}$ & $3.80 \%$ & above 1500 Eur & $22.78 \%$ \\
\hline Total sum & $100.00 \%$ & Total sum & $100.00 \%$ & Total sum & $100.00 \%$ \\
\hline
\end{tabular}

Source: Author.

In the conclusions drawn from the collected data, we are of course aware of the fact that it is a smaller sample and unevenly distributed in proportion to the number and structure of the population, but to verify certain predicted tendencies, determinants or directions in the development of consumption of these components, our approach for this purpose is sufficient .

\section{Results}

Productive components of consumption are typical that they are not indispensable for survival, but their importance in the consumer basket is increasing only after reaching a certain standard of living for households. In the long run, their importance should increase significantly in order to improve the quality of life and overall development [18].

\subsection{Key real determinants forming the productive components of consumption in SR}

The first and partly conditional determinant is income, which has been increasing in Slovakia over the last period, yearly (in line with the rise in the minimum wage), which should create very favorable conditions in relation to the categories of expenditure pursued. Here, in the first step, we will think about the causes of income growth. According to the OECD list, in 2015, we were among the most working-class countries in terms of hours worked, and the average Slovak employed about one hour more in the day and excelled in work in difficult conditions, at night and over weekends where there are currently approved overtime raises. At present, the situation has changed slightly and overtime hours have fallen. Our survey (Table 2) has shown that overtime hours are least worked by people with the lowest income, the higher the income, the greater the willingness to work more. We did not assess attitude towards work. From the point of view of the willingness to undertake the risk, the ratio of the answers is balanced and in the context of the income there is no dependence, so we consider this aspect considerably individual. However, very interesting were the answers to the question about the decision making and the attitude towards it in relation to the monitored groups of expenditures. Up to $72 \%$ consider themselves to be people who think and plan things thoroughly rather than to spend on the expenses of that nature. The remaining $27.85 \%$ of respondents are impulsive. In relation to their income, low-income categories do not allow themselves to behave impulsively, on the contrary, 
with the increase in the income, the amount of people with impulsive attitude rises. In the highest income category, the ratio is almost $1: 1$.

Table 2. Descriptive characteristics of the target sample (Survey questions 4-5)

\begin{tabular}{|l|c|l|c|}
\hline Question (4.) & $\begin{array}{c}\text { Average } \\
\text { overtime }\end{array}$ & Question (5.) & $\begin{array}{c}\text { Do you like to undertake } \\
\text { risk? }\end{array}$ \\
\hline Work nonstop & $2.53 \%$ & Yes & $39.24 \%$ \\
\hline $\begin{array}{l}\text { On average up to } \\
\text { three hours }\end{array}$ & $7.59 \%$ & I cannot judge & $24.05 \%$ \\
\hline $\begin{array}{l}\text { On average up to two } \\
\text { hours }\end{array}$ & $6.33 \%$ & No & $36.71 \%$ \\
\hline On average an hour & $18.99 \%$ & Total sum & $100.00 \%$ \\
\hline $\begin{array}{l}\text { On average a houlf } \\
\text { hour }\end{array}$ & $36.71 \%$ & Otázka č. (6.) & $\begin{array}{c}\text { Opinion on own decision- } \\
\text { making on spending? }\end{array}$ \\
\hline No overtime & $26.58 \%$ & Acts impulsively more often & $27.85 \%$ \\
\hline $\begin{array}{l}\text { Currently } \\
\text { unemployed }\end{array}$ & $1.27 \%$ & Thinks and plans more often & $72.15 \%$ \\
\hline Total sum & $100.00 \%$ & Total sum & $100.00 \%$ \\
\hline
\end{tabular}

Source: Author.

In the second step relating to income, we might notice that if households work on average more, they have less time to develop productive components of consumption and therefore have less time for education, culture, relaxation. During this period of time, if they would like to change their spending on productive aspects of consumption, they would probably have to spend less time at work, which would be a loss of income in the first place (provided they have paid or otherwise rewarded overtime). This view is supported in part by Poštová Banka's analysis of 2014, when it examined the proportion of employees working at night, evening, Saturday and Sunday. At the top of the list were Slovaks, $16 \%$ of them working at night, $25.2 \%$ in the evening, $24.4 \%$ on Saturday and $19.2 \%$ on Sunday [19]. This fact affects not only the level of income through mandatory surcharges but also the level of quality of life in households in which the provider is missing in the dedicated common time, which in turn limits the application of the aforementioned expenses. Our survey showed that up to a third of the respondents spend 1-3 hours of overtime a day, a third spends on average a half an hour, and about a third of the respondents does not work any overtime.

The determinant of wealth is largely influenced by looking at debt issues, where appropriate, the nature or type and nature of goods or services purchased by the individual or household debt. The determinant price level and interest rate are also closely linked to this issue. For both determinants, the change in the structure of consumption in terms of long-term sustainability and continuous targeted improvement of the income situation is the consequence or key to addressing. The survey revealed, based on the last open question, that most of the people surveyed do not think about the productive components of consumption at all. Of the total number of respondents, $72 \%$ said so. From this, up to $50 \%$ of the respondents given this question (not asked) simplified their answer, and repeated only the offered examples to this question. Only $18 \%$ of respondents given this question seriously considered and captured the basic idea of the survey and attempted to elaborate on it.

Allocation and redistribution of pensions, and tax policy are a very important determinant of the formation of consumption and, in particular, of productive components or the creation of savings. The main idea and reason for mentioning this determinant is the fact that the state affects the income of the tax payers, changes the relative prices of goods 
and services (excise duty) and also consumer choices, choosing employment, health care, choosing a place of residence (county town, village, etc.) and waste management etc. At present, for example, a reduced VAT rate from $20 \%$ to $10 \%$ is applied for medicines, medical devices and books, which directly falls under the monitored issue.

Another determinant is the behavior of households, which is largely influenced by their optimistic or pessimistic expectations. Whether optimistic or pessimistic, they are always associated with a certain amount of uncertainty or mistrust, which is also reflected in consumer decision-making in households. Household decision-making aims to keep the household at at least a constant level of its assets, and spend only on the incomes of individual assets. Savings are mainly taken as a policy to mitigate variations in retirement. Nowadays, according to our survey, the expectations of people that are too optimistic, which distort their decisions in the direction of less caution when deciding on productive components of consumption, are at the top of our survey. In addition to expectations, behavior and decision-making influence other factors, depending on the focus of specific types of expenditure.

Other influential determinants include demographic and structural characteristics relating to individuals or households, psychological determinants, and last but not least cultural influences and social determinants [3].

\subsubsection{Main determinants forming expenditure on education}

The analysis of the educational structure of the population in relation to the income level revealed that the amount of income is determined by the degree of education achieved only with a few exceptions [21]. Education is therefore something essential for development and success in the knowledge society and every economy. It represents a kind of investment for every individual, thanks to which they can gradually increase not only income, but also the knowledge to make it more efficient and to work more efficiently.

He level of spending on education for individual types of households in Slovakia is, on average, around $0.3-0.6 \%$ of the total net cash expenditure of households, which is very low. The expenditure on education was higher in households with a self-employed provider. The reason for the low spending on education can be busyness from the point of view of work responsibilities that go beyond normal working hours, it may also be a lack of motivation for self-education, other spending priorities (eg spending on other members of the family, children) or still a misconception about the fact that one is able to complete one school and no further training is needed. All of these factors were confirmed in the survey and the variability of the responses was very large even though $97 \%$ of the respondents considered spending on education to be beneficial and useful. Which is heavily opposed to the answers they developed in the questionnaire survey subsequently. In the following Table 3, the answers to the question of the benefits of education are what their point of view was. From the answers, it is obvious that the respondents noticed the reaction of the environment and felt the positive and the negative response that came out of it. This table also shows the benefits of spending on education based on higher income, non-financial benefits, knowledge and contacts, and the good feeling they had with themselves. All of these variables are of great importance in the long run and also have an impact on the level of their monetary and mental wealth. 
Table 3. If you saw any benefits in education, what were they? (Survey question 9)

\begin{tabular}{|l|c|}
\hline Respondents' answers, question 9 & In \% \\
\hline I refuse to answer, it's private & $2.53 \%$ \\
\hline I got the job of my dreams, and that pleases me & $3.80 \%$ \\
\hline $\begin{array}{l}\text { I have gained valuable business contacts for people with whom I will continue to } \\
\text { share my work experiences }\end{array}$ & $15.19 \%$ \\
\hline I have received other non-financial benefits through education & $3.80 \%$ \\
\hline $\begin{array}{l}\text { I have benefited from other non-financial benefits through education, I have } \\
\text { improved my knowledge / abilities through education which has been positively } \\
\text { evaluated by my environment }\end{array}$ & $7.59 \%$ \\
\hline $\begin{array}{l}\text { I have gained other non-financial benefits, accelerated, streamlined and improved } \\
\text { my work without any feedback from my environment }\end{array}$ & $1.27 \%$ \\
\hline $\begin{array}{l}\text { I improved my knowledge / abilities through education which was positively } \\
\text { evaluated by my environment and I had a good feeling about it }\end{array}$ & $35.44 \%$ \\
\hline $\begin{array}{l}\text { I accelerated, streamlined and improved my work without any feedback from the } \\
\text { environment }\end{array}$ & $12.66 \%$ \\
\hline I have gotten a raise in my salary through education & $7.59 \%$ \\
\hline $\begin{array}{l}\text { Several of the benefits mentioned together (increased salary, contacts, non-financial } \\
\text { benefits) }\end{array}$ & $10.13 \%$ \\
\hline Total sum: & $\mathbf{1 0 0 . 0 0 \%}$ \\
\hline
\end{tabular}

Source: Author.

\subsubsection{Main determinants forming healthcare expenditure}

For this group of expenditure, it is necessary to say that the health of the population is not improving at all and the number of reported occupational diseases is increasing. In fact, mediated factors are declining in terms of disease prevention, for example the consumption of vegetables, partly fruits and the production of own food [22]. So, what form of prevention is being implemented and therefore what influences real savings in healthcare spending? We found the answer to this question in part in the questionnaire survey, but the question of the objectivity of the answers is questionable as the questionnaire results partly contradict some statistical data. However, it can be said that, from the point of view of the amount of prevention, the respondents seek it from 34\% 1-3 times a year, 55.7\% realize it on a monthly basis and $8.8 \%$ seek it on weekly or daily basis, indicating the lack of intensity of prevention, although in terms of the content and attitude of the respondents, the structure and the satisfaction $(86 \%$ consider the prevention of their health problems as sufficient) are almost ideal in the following table.

An interesting finding is the fact that Slovakia has a leading position within the OECD countries when considering the consumption and spending on medicine. Why is it? According to the survey, the respondent considered this form a suitable type of prevention and protection of health as a reason for their purchase. This belief is probably due to marketing and advertising, which is richly represented in several forms. 
Table 4. How do you prevent disease and improve your health? (Survey question 11)

\begin{tabular}{|l|c|}
\hline Answers to question 11 (method of disease prevention) & In \% \\
\hline I'm looking for alternative forms of prevention and treatment from experts & $1.27 \%$ \\
\hline $\begin{array}{l}\text { I buy enough fresh fruit, vegetables, legumes and everything that is necessary for a } \\
\text { varied diet }\end{array}$ & $31.65 \%$ \\
\hline I buy herbal and natural remedies in specialized stores & $7.59 \%$ \\
\hline I use multiple options of prevention at once & $22.78 \%$ \\
\hline $\begin{array}{l}\text { I buy minerals and vitamins in pharmacies, and herbal and natural remedies in } \\
\text { specialized stores }\end{array}$ & $17.72 \%$ \\
\hline I irregularly go to the sauna, swim, douse in cold water, etc. & $2.53 \%$ \\
\hline I do not have any health prevention expenses, it is not necessary & $5.06 \%$ \\
\hline I regularly go to baths, regularly go to the sauna, swim, douse in cold water, etc., & $6.33 \%$ \\
\hline I grow my own fruits, vegetables + raise own poultry & $2.53 \%$ \\
\hline No response & $2.53 \%$ \\
\hline Total sum: & $\mathbf{1 0 0 . 0 0 \%}$ \\
\hline
\end{tabular}

Source: Author.

\subsubsection{Main determinants of recreation and culture expenditure}

Expenditure on recreation and culture is closely related to the time spent on individual spheres of quality of life. They cross through each other. If a person spends more time in the workplace, and in the sphere of one-off or out-of-work expenses, the sphere of free time, in which these expenditures in particular belong, shortens. This trend was confirmed by our survey. With this expenditure, the notion of motivation comes first, as the attitude of an individual towards spheres depends directly on it. As we know, motivation expresses the process, while the motif expresses a hypothetical disposition to this process (for example, the need to relax, to relax, to enjoy a cultural experience or other similar primary or secondary motives), so we should focus on the motives and the process separately and answer the question as to why is there a difference between Slovak households in this spending group and what forces the households to reduce or cut this share of expenditure.

In the first step, we determined whether or not the households spent any expenditure on recreation at all. Of the respondents, $88 \%$ answered positively, the remaining responded negatively, and most of the reasons stated a lack of time. What is also confirmed by the next question is that we have focused on the number of holidays, where up to $81.6 \%$ of respondents said that they go on holiday once or twice maximum. In terms of expenditure, we consider this value to be highly distorted and very variable, so I do not mention it. On the question of satisfaction, $83 \%$ responded that they were satisfied with the holiday. Reasons for dissatisfaction with the others were related to insufficient holidays, dissatisfaction with the location or a busy household due to young children. It is very interesting to note that if we asked whether they considered after their holiday that they have to change something the next year, $62.8 \%$ of the respondents answered yes. Those who answered yes, we asked whether they really did. Here $22.8 \%$ of respondents answered that they did not. And as a reason they have mentioned, for example, insufficient preparation or lessons from mistakes, little time or small children, which make it impossible to plan and organize things. For questions about this type of spending, it also happened that $79 \%$ of the respondents did not read the question at the end and their response was not related at all to what we asked about. This fact also speaks about how people perceive and focus very little. Often they think quickly, intuitively, and do not know what the person is 
asking specifically, or they make questions up. This also influences decision-making. If they are absent mentally, it also affects their decision-making, behavior, and action.

The second group of expenditure is spending on culture. $93.7 \%$ of the respondents from our sample spend expenses on it. The rest of them said they did not do it, and the reason is again the lack of time, money or inadequate and uninteresting possible choice of cultural events. Very interesting was the answer that it is difficult to change the habit, you just get used to some sort of thing and even incorporate some cultural action into their schedule is extremely difficult, even if they wanted to incorporate it into the schedule. Which is confirmed by the theory of behavioral economists and the unomittable role of habit.

\section{Conclusion}

The aim of the article is, using the decision-making mechanism of the individual and related to that, the household, to determine the main determinants of the formation of their productive components of consumption in real conditions. By recognizing these determinants, the partial decision-making issues were clarified and opened space for possible options to shape household behavior in specific SR conditions. Besides the basic determinants of consumption such as income, wealth, interest rate, price level, tax conditions, demographic, societal and cultural determinants, our survey confirmed the severity of the so-called psychological factors in terms of behavioral economists' conclusions, but focusing on specific conditions of Slovakia. Even with productive components of consumption and spending on them, people behave emotionally, intuitively, habitually and comfortably. People avoid unnecessary thinking, deceiving themselves and choosing in the most simple and short ways. Which is exactly what is a big risk with these components of consumption. As a result, productive components have a positive effect on the lives of individuals from an economic and mental perspective in the long run, but in the short term, the spending of resources now represents a reduction in the available resources in the household budget, which is partly done with impunity, and these expenses are for a number of reasons uninteresting.

It is generally known that the current knowledge economy is based on four basic pillars: education, corresponding to the information structure, clear rules of the game and the existence of an innovation system [3]. The justification of the consumed productive components of consumption coincides with several pillars of the knowledge economy. The core is not only to economically evaluate expenditure groups but also to know their themes, expectations and personal profile of people living in that country and only then is it possible to reliably predict the development of consumption or its selected components.

From our survey, many respondents have surprisingly focused their view on ecology, which is also productive in nature, but it is the so-called "environmentally conscious consumption", which is the expression of qualitative individualisation, which we can regard as voluntary or intentional modesty in the behavior of some households. However, it is debatable whether this environmentally-friendly lifestyle is really reaching out to potential consumers or it is just a modern trend to talk about.

\section{Recommendations and Suggestions}

The conclusions of this article point out that household decision-making mediated by individuals is influenced by several factors in parallel, and each of them represents a sort of channel through which action can be taken. Of particular importance in the decisionmaking mechanism are the psychological factors, which we have proven in our article. 
From the perspective of economic policy recommendations, emphasis should be placed on taking these facts into account when generating government economic policies. Very interesting and now often used is the term "libertarian paternalism" which can be used not only in the sense of better information but also in the sense of targeted measures by governments in order to guide people's decision in a desirable direction without being limited [23-25].

In addition to these positives, it is criticized in a negative sense that it directs the decision-making and behavior of an individual, regardless of the description of what complex human spirit it should rely on and relies heavily on economic and psychological factors alone. At the same time, the multiplication of researches and comparisons or the new "paternalism" is beneficial and, compared to the old one, makes real progress [26]. Finally, there is another worrying tendency that is associated with the growth of some experiments in connection with "paternalism," and it is questionable to what extent they are known and their consequences are addressed. Also, with regard to the academic sphere, they are increasingly preferring and appreciating academic knowledge of psychological, neurological and behavioral sciences, with the science of social studies potentially deteriorating and being marginalized [27]. This discussion obviously brings many interesting points of view, but also opportunities to develop a moral, ethical and perspective correct form of "paternalism". However, in addition to this discussion, we are going back to the first possible form of action, in raising awareness as a possible policy measure, also here are limitations, for example in the limited attention of people who can not use all available information efficiently in the event of some kind of attention already exhausted, for example by fatigue, or by the overload of information, then decision making becomes intuitive and shallow. It therefore stops taking into account important aspects of the situation, and such decision-making can lead to suboptimal results by overestimating the importance of the most pronounced stimuli and ignoring the less visible ones. This could be avoided by some kind of help in terms of targeted databases or institutions through which people could learn the most accurate information. In general, this is precisely the aforementioned aid by the so-called "nudging", which aims to complement decisionmaking processes with elements that help people make the same intuitive decisions as they would if their cognitive resources were not restricted [28]. At the same time, we are at odds with the possible negative "paternalism" in keeping with ethical and moral standards or some sort of targeted manipulation.

From the point of view of a specific type of measure aimed at a particular individual, it can be, for example, a reform of education that would include content with due importance, depth and thorough preparation of a subject focusing on increased awareness of health and healthy lifestyles, financial literacy or targeted support of critical and logical thinking and decision-making psychology, which would improve decision-making over the longer term (health, education, consumption, marketing, etc.). In so-called financial literacy under the current condition, certain savings schemes that would allow to systematically generate savings or solve the financial situation of individuals and households in the long run in due time, would be appropriate. For example, it is possible to create savings for education and to motivate people to think ahead, and such products by banks and the state could also be favored and supported. There are, of course, many choices.

The already established and partly used tools include tax policy and the use of lower tax rates, for example, VAT (Value Added Tax) on selected types of supported household expenditure. In this measure, it would be appropriate to focus on the productive ingredients in consumption and to favor those with the appropriate disclosure of reasons. This type of measure can be used across all of the monitored spending groups and is just a selection of several options that could help to improve the benefits of such measures, with the fact that 
they would be thoroughly evaluated and published for possible corrections in cooperation with the academic sphere that deals with the issue in detail.

\section{References}

1. J. Lisý a kol., Dejiny ekonomických teórií. Wolters Kluwer, (2003)

2. L. Madarász, J. Vaščák, R. Andoga. T. Karol', Rozhodovanie, zložitost' a neurčitost', teória a prax. Košice: Elfa, (2010)

3. M. Psárska, Mikroekonomické aspekty spotreby domácnotí SR v nových ekonomických podmienkach. Dissertation thesis, (2013)

4. J. Hlaváček, M. Hlaváček, Zobecnená mikroekonomie (2010)

5. P. Sirůček a kol., Hospodářské dějiny a ekonomické teorie. Prague: Karolinum, (2007)

6. R. H. Frank, Mikroekonomie a chování. Prague: Svoboda, (1995)

7. V. Holková., Ekonomická vzácnost' a racionálne rozhodovanie z pohl'adu mikroekonomickej teórie. Proceedings of the EAPG workshop 2011: Economic analysis and Policy Group, 1-8, (2011)

8. R. Valenčík, Ekonomie - Jak ji chápat a k cemu je? (Doplnující text ke studiu mikroekonomie na magisterském stupni). Marathon, (53), (2004)

9. D. Ariely, Jak drahá je intuice. Práh, (2011)

10. E. Andrade, D. Ariely, The Enduring Impact of Transient Emotions on Decision Making. Organizational Behavior and Human Decision Processes, 109(1), 1-8, (2009)

11. P. Singer, Famina, Affluence, and Morality. Philosophy and Public Affairs, 1(1), 229243, (1972)

12. D. Small, G. Loewenstein, The Devil You Know: The Effects of Identifiability on Punishment. Journal of Behavioral Decision Making 18(5), 311-318, (2005)

13. D. Small, G. Loewenstein, Helping a Victim or Helping the Victim: Altruism and Identifiability. Journal of Risk and Uncertainty, 26(1), 5-13, (2003)

14. D. Kahneman, Vjeho prednáške z udelovania Nobelovej ceny za ekonómiu, z 8.decembra 2002, ktorej názov je „Mapy ohraničenej racionality: Pohl’ad na intuitivny úsudok a vol'bu“, (2002)

15. D. Ariely, Jak drahé je zdarma. Práh, (2009)

16. G. S. Becker, K. M. Murphy, The Theory of Rational Addiction. Journal of Political Economy, 96(4), 675-700, (1986)

17. R. H. Thaler, C. R. Sunstein, Nudge (štouch): Jak postrčit lidi k lepšimu rozhodovácní o zdraví, majetku a štěstí. Kniha Zlín, (2010)

18. M. Psárska, Produktívne zložky spotreby domácností SR a ich aktuálny vývoj v kontexte blahobytu / Marianna Psárska. - VEGA 1/0570/11. QUAERE 2012 Reviewed Proceedings of the Interdisciplinary International Scientific Conference of PhD Students, Hradec Králové, Czech Republic, (2012)

19. The Post Bank [online], Available at: https://openiazoch.zoznam.sk/cl/160648/Slovaciopat-na-cele-rebricka-Stvrtina-pravidelne-pracuje-vecer-a-kazdy-siesty-chodi-doprace-v-noci (2018)

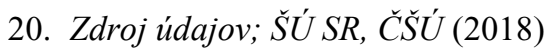

21. E. Čitáryová, T. Chrenko, Analysis of the educational structure of Slovak population in terms of income levels. Medzinárodný seminár: Kvantitatívne metódy v ekonómií, (2011) 
22. Štatistická ročenka Slovenskej republiky 2016. Veda, (2017)

23. R. H. Thaler, Neočekávané chováni, Přiběh behaviorální ekonomie. Argo, Dokořán, (2015)

24. A. Belayanin, Richard Thaler and behavioral economics: From the lab experiments to the practice of nudging. Nobel Memorial Prize in Economic Sciences 2017, 1, 5-25, (2018)

25. R. H. Thaler, Nudge, not sludge. Science, 361(6401), 431-431, (2018)

26. B. Pickett, The New Paternalists. POLITY, 50(2), 300-329, (2018)

27. R. Jones, M. Whitehead, Politics done like science': Critical perspectives on psychological governance and the experimental state. Environment and planning $d$ society \& space, 36(2), 313-330, (2018)

28. P. Houdek, P. Koblovský, D. Št’astný, M. Vranka, Consumer Decision Making in the Information Age. Society, 55(5), 422-429, (2018). 